\title{
Reseña sobre Ricardo Laleff Ilieff. Lo político y la derrota: Un contrapunto entre Antonio Gramsci y Carl Schmitt. Madrid: Guillermo Escolar Editor (2020)
}

\author{
Iván Nicolás Montes-Pastor ${ }^{1}$
}

\section{Revista}

\section{Educación y Sociedad}

Citar como: Montes-Pastor, I. (2021). Reseña sobre Ricardo Laleff Ilieff. Lo político y la derrota: Un contrapunto entre Antonio Gramsci y Carl Schmitt. Madrid: Guillermo Escolar Editor

(2020). Revista Educación y Sociedad, 02(03), 58-59.

doi: $10.53940 /$ reys.v2i3.66

Artículo recibido: 20-06-2021 Artículo aprobado: 15-07-2021 Arbitrado por pares

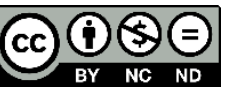

\section{ACEES}

Ricardo Laleff es un intelectual argentino volcado al estudio de la teoría política y social. Por su amplio recorrido en la producción de conocimiento, era de esperarse que su reciente libro haga honor a su orientación dentro de los estudios de ciencia política. A lo largo de su obra, la pluma del autor pone en evidencia sus innegables capacidades intelectuales para estudiar de manera rigurosa a dos grandes pensadores acerca de lo político.

Para ello, el autor sigue a Theodor Adorno para servirse de la noción de contrapunto desarrollada en la "Filosofía de la nueva música". Así, la noción de contrapunto de Adorno analiza las innovaciones del dodecafonismo de Arnold Schönberg. Entonces, la función del contrapunto es una organización de la música en donde cada sonido cumple exactamente su función de textura (Laleff, 2020, p.18).

En este sentido, la noción de contrapunto implica cierta distancia e independencia entre las notas musicales que en el libro toman la forma de dos autores. Antonio Gramsci y Carl Schmitt son las dos notas musicales que trenzan el hilo argumental del escrito.

El volumen presentado por Ricardo Laleff hace un profundo repaso sobre la producción intelectual de Gramsci y Schmitt, pero no se agota en ello. También plantera un análisis de los teóricos que nutrieron el pensamiento de ambos autores. 
Así, el libro no solo plantea un análisis de Schmitt desde Schmitt, sino que también presenta una lectura de Schmitt desde Joseph de Maistre, Donoso Cortés, George Sorel, Thomas Hobbes, entre otros tantos autores. Entonces, el estudio de Laleff también puede ser pensado como un trabajo arqueológico que analiza cambios y continuidades en las fuentes que inspiraron a ambos autores.

Cabe mencionar que el pensamiento contrapuntístico retomado en el libro entiende cada nota desde su propia complejidad, sin forzar falsos diálogos entre ambos autores. Sin embargo, es posible mencionar la derrota como un punto de contacto.

Si Gramsci y Schmitt pueden ser caracterizados como pensadores derrotados, es porque lo han sido más allá de sus biografías y más allá también de las particularidades de sus prácticas partidarias. Pueden serlo porque adscribieron sus elucubraciones en discursos cuyos rótulos debían ser modificados, es decir, ser considerados pertinentes en la medida en que aludían razones históricamente operantes. Para tales perspectivas, esa disputa era una disputa no solo intelectual sino, precisamente conceptual y política, es decir, teórico-política (Laleff Ilieff, 2020, p.196).

Dicho esto, Gramsci y Schmitt pueden ser leídos como dos autores que desenvainaban fuertes argumentos contra las revoluciones de 1848 , pero que a la vez se vieron derrotados frente a la misma. Por un lado, la perspectiva marxista de Antonio Gramsci se preocupó por las condiciones necesarias para una revolución de la clase obrera. Por otro lado, Carl Schmitt recuperó un marco teórico contrarrevolucionario para mostrarse en contra del liberalismo y el marxismo.

El libro de Ricardo Laleff nos invita a analizar a dos autores derrotados, pero también a pensar lo político a través de una recuperación ontológica. Asimismo, las líneas del escrito pueden servir de brújula para revertir ciertas contradicciones en completa vigencia.

En esta línea, los aportes teóricos de Antonio Gramsci y Carl Schmitt siguen siendo una piedra de toque para muchas investigaciones contemporáneas. Quizá el tiempo apaciguó el clima político y social en el que escribieron ambos pensadores para darles la razón. Ahora, la derecha lee a Gramsci y la izquierda a Schmitt. Sin duda, el libro de Ricardo Laleff es primordial para un mejor entendimiento.

\section{Referencias}

Laleff, R. (2020). Lo Político y la derrota: un contrapunto entre Antonio Gramsci y Carl Schmitt. Madrid, España: Guillermo Escolar Editor. 